\title{
Discourse Deixis and Anaphora in L2 Writing
}

\author{
Derya Çokal \\ ORCID ID: 0000-0002-5653-1412 \\ Queen Mary University of London School of Engineering and Computer \\ Science, Peter Landing Building 327 Mile End Road London E1 4FZ \\ d.cokal@gmul.ac.uk
}

(Received 28 August 2018; accepted 21 May 2019)

\begin{abstract}
This study investigates the use of $i t$, this, and that by L1 Turkish learners of English in academic writings from two perspectives: Rhetorical Structure Theory (Marcu, 2000) and Relevance Theory (Sperber \& Wilson, 1986/95). The study examines the expressions as interface phenomena concerning the attentional state and the intentional structure of discourse and shows deictics contribute different higher-level explicatures to relations between discourse units. The L2 data analyses reveal (1) it is used as a discourse deictic at lower levels of proficiency; (2) this is the default demonstrative for reference establishment and maintenance; (3) learners tend to use demonstratives in rhetorical relations that are atypical of written academic discourse; and (4) learners demonstrate non-optimal processing of pointing acts. In addition, to implications of results, suggestions for further research and instruction are proposed.
\end{abstract}

Key words: interlanguage demonstratives, rhetorical relations, second language writing, discourse deixis, basic-level explicature, higher-level explicature

\section{Türkçe-İngilizce İkidilli Türk Konuşucuların Metin Gönderimi ve İşaret Adılı Kullanımları}

ÖZ: Bu çalışma, Türkçe-İngilizce ikidilli konuşucuların akademik yazılarında metin gönderimi it ve metin işaret adılları this/that'i Retorik Yapı Kuramı (Marcu, 2000) ve Bağıntı Kuramı (Sperber \& Wilson, 1986; 1995) çerçevesinde incelemektedir. Çözümleme sonucunda elde edilen bulgular şunlardır: (1) İngilizce yeterlilil seviyesi düşük olan konuşucular metin gönderimi it'i işaret adılı olarak kullanmaktadır; (2) ikidilli Türk konuşucular metin işaret adıllarını uygun olmayan retorik yapıda kullanma eğilimindedir. Bunlara ek olarak, bu çalışmada metin gönderim ve işaret adıllarının öğretimiyle ilgili önerilerde bulunulmuştur.

Anahtar sözcükler: aradil işaret adılları, retorik ilişkiler, ikinci dilde yazma, söylem gösterimi 


\section{Introduction}

In this paper, we examine discourse deictic use of it, this and that by L1 Turkish learners of English at various levels in L2 education. The purpose of this study is to understand the interlanguage pragmatics of the expressions in written discourse. Employing the framework of both Rhetorical Structure Theory (Marcu, 2002) and Relevance Theory (Sperber \& Wilson 1995), we examine the expressions as interface phenomena concerning the attentional state and the intentional structure of discourse (Grosz \& Sidner, 1986), and show that deictics contribute to different higher-level explicatures regarding the relations between discourse units.

\section{Discourse Deictic Pronominals and Interlanguage Writing}

Besides mastery of the lexico-grammatical system, learning to write in an L2 demands knowledge of form-function mappings across a variety of domains (e.g., reference tracking and topic-comment structures) and a metalinguistic awareness of the cognitive and the socio-psychological expectations of the audience. In relevance-theoretic terms, successful writing involves mutual adjustments of the writer's and the reader's cognitive environments and the tracking of the hierarchical semantic and pragmatic relations over spans of discourse units. In this respect, discourse deixis, where reference is made to a previous utterance or a part of the discourse (e.g., 'in the foregoing section'), is one way of establishing textual connectivity.

Discourse deictic demonstratives are rather special. On the one hand, they "coordinate the interlocutors' joint focus of attention" (Diessel, 2006, p. 465); on the other hand, they are intertwined with propositional attitude expression (Cornish, 2001; 2008) and the relations between the parts of a discourse (Grosz $\&$ Sidner 1986, p. 176). Efficient use of these expressions thus requires writers to maintain global coherence and keep track of what information is accessible to readers, whilst maintaining an awareness of the stance they wish to display toward this information.

Although style manuals advise avoidance of the demonstratives for discourse deixis (see Strunk and White, cited in Webber, 1991, p. 1), they are common in written texts in English (Gundel, Hedberg, \& Zacharski, 2004). A number of scholars in the SLA field also claim that the presence of demonstratives is a sign of increased mastery of the cohesive system of a language (e.g., Murphy, 2001). Acquisition of their appropriate usage is therefore important. Furthermore, since languages show subtle distinctions in the pragmatics of demonstratives, it is crucial to investigate their development in interlanguage systems (hereafter IL). In written English discourse, this and that are the two pro-forms that point predominantly to non-nominal discourse entities. The pronoun it is used to a lesser extent in this manner (Brown-Schmidt, Byron \& Tanenhaus, 2005; Çokal, 
Sturt \& Ferreira, 2016; Webber, 1988). The referents of demonstratives may be propositions, clauses, sentences, or larger discourse segments such as paragraphs or sections in a text (Brown-Schmidt et al., 2005; Çokal et al., 2016; Webber, 1990). Example 1 illustrates how the intended referent of that in (1d) is the previous clause and the discourse units spanning (1a-c) in (1d').

(1) a. For his part in their joint project, John built a two-armed robot.

b. He had learned about robotics in CSE391.

c. For her part, Mary taught it to play the saxophone.

d. That took her six months.

d'. That earned them both As.

(Webber 1991, p. 6)

What is significant for the present investigation is that the resolution of the referent of that requires noticing both the semantic and the textual relations between the sentence in which the demonstrative is used and the preceding discourse units.

Discourse deixis involves processing of both the grammatical structure and the informative content of a text. Hence, discourse deictics need to be investigated both in terms of the linguistic structures in which they occur and the intentional structure of the discourse, that is, the communicative intention of an utterance or units in discourse and the relationships between these units (Grosz \& Sidner 1986, p. 175-8). In this study we thus assume that it, this and that concern the interface of these two structures.

\section{1 'It', 'This' and 'That' in (Written) Discourse}

The literature on deixis reveals a move away from describing the demonstratives as proximal vs. distal toward investigating their cognitive and modal properties (e.g., Cornish, 2001; 2008; Çokal, Sturt \& Ferreira, 2014; 2016). We find such proposals significant in that the studies build their descriptions on cognitive processing mechanisms and show that discourse deixis is an interactional achievement.

Cornish (2001), for example, identifies both attentional and the intentional properties for it, this and that. For it, Cornish states that "the attention of the discourse partners is already focused on the intended referent (which is topical to a degree), [and that] the referent constitutes shared information" (p. 313). In the case of this, "the speaker is establishing the referent cognitively within his/her discourse sphere, thereby tacitly associating and involving him/herself with it" (ibid.: 312). That, on the other hand, signals that "the intended referent 
is not cognitively or subjectively within his/her discourse sphere, though this use may well indicate that $\mathrm{s} / \mathrm{he}$ is aligning her/himself with the addressee" (ibid.: 312-313, emphases added).

Excerpt (2) illustrates the use of this, while (3) reflects the contrast between it and that:

(2) (a) The basic idea of Marr's model was that edge maps are computed by first obtaining a smoothed version of the image. (b) This is done by convolving the image intensity with a set of Gaussian low-pass filters over a range of spatial scales.

(Çokal, 2005, p. 39)

(3) a) It's always been presumed that when the glaciers receded, the area got very hot. (b) The Folsom men couldn't adapt, and they died out. (c) That's what is supposed to have happened. (d) It's the textbook dogma. (e) But it's wrong.

(adapted from Webber, 1988, p. 114)

Of note is that this and that turn propositions into discourse entities of a nominal type (i.e., the noun clause in (2a) and the textual span (3a-b) or (3b)), depending on the interpretation of the intentional structure of the text. Comparing (2) and (3), we observe that this and that are used in different "modal properties" (e.g., topic comment, contrast or explanation relations), that is, with different communicative intentions. This in (2) is used in a mean relation between units (a) and (b) whereas that in (3) occurs in a topic-comment relation between (3a, b-c) (see Section 2.2 for different modal properties/propositional attitudes). They thus function as metadiscursive devices that highlight portions of texts for further expansion and contribute to the mental representation of the unfolding discourse by indicating the cognitive status of the intended referents for the speaker/addressee (i.e., the attentional state). ${ }^{1}$ This means that the demonstratives and the pronoun it are sensitive to the intentional structure (Grosz \& Sidner, 1986, p. 178). An investigation of their inter-relationship with discourse units within the analytic framework of RST can thus shed light on their pragmatic meaning.

\footnotetext{
1 'Attentional state' refers to the cognitive status of referents as 'focus of attention' (Grosz and Sidner 1986: 175). The term does not mean 'focus as information status' (see Strauss 2002).
} 


\section{2 'This' and 'That' in RST and Linguistic Processing}

A comparison of the use of the demonstratives in the preceding section falls in line with a study carried out by Çokal (2005) on the occurrence of this and that in written academic discourse and Gundel, Hedberg, and Zacharski's (1988) analysis of the expressions across a variety of genres. Çokal (2005) looked into the correspondence between rhetorical relations among discourse units and the use of this and that, employing RST (Mann and Thompson, 1988; Marcu, 2000). The rationale for this analytic procedure is based on Webber's observation that only certain discourse segments in focus can yield referents for demonstrative pronouns (Webber 1991, p. 2). This observation is also in tune with Mann and Thompson's (1988) statement that textual units and rhetorical predicates are necessary in the resolution of demonstratives.

RST views texts not only as strings of clauses but as groups of hierarchically organized units, which bear various informative and intentional relations to each other. Analyses in RST identify the hierarchical structure in the text and describe the relations therein and the extent of the related units. In RST propositions are identified as 'nuclei' and 'satellites.' Nuclei are central units in information structure and enter into semantic relations with other units called satellites. Some examples of semantic relations are 'interpretation', 'explanation', 'topiccomment', and 'contrast'. In Figure 1, the first unit presents a research problem and the second unit interprets the problem in the framework of the author's study. The second unit thus further explains the problem ('This means that...'), while the third unit presents an antithesis to the interpretation of the author ('That does not mean that...').

Figure 1. Analysis of 'interpretation' and 'antithesis' relations in Rhetorical Structure Theory

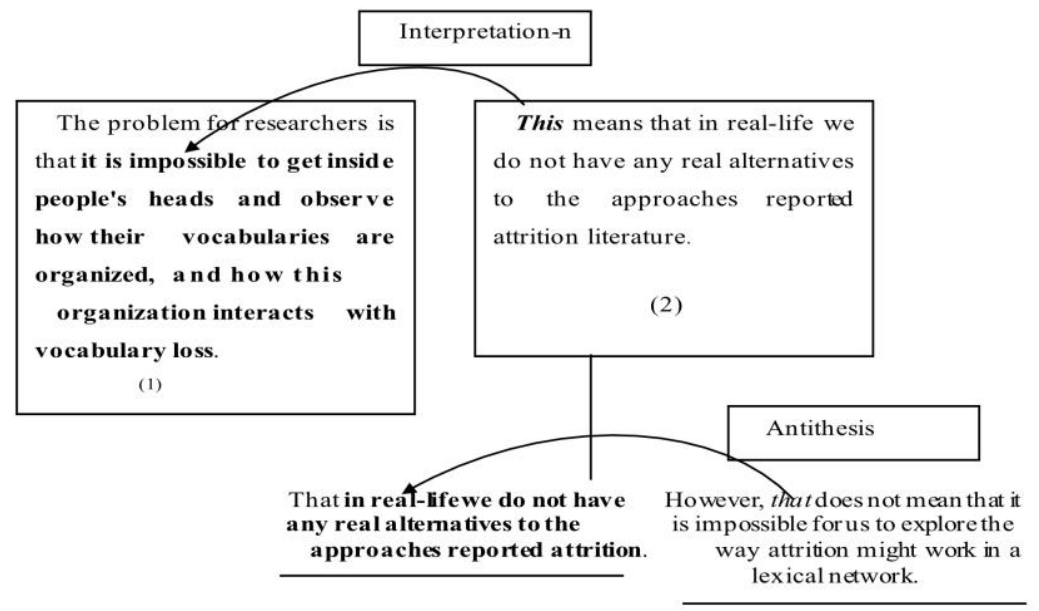


Çokal finds that the majority of the tokens of this fall into discourse units that elaborate a topic through 'explanation', 'interpretation' and 'result' relations (2005, p. 98). That is, discourse deictic this signals persistence of the speaker on the same topic (see Table 1). In contrast, that is used predominantly in 'contrast', 'condition', and 'topic-comment' relations (Çokal, 2005, p. 99; see Table 2).

Table 1. Rhetorical relations with this

\begin{tabular}{lrr}
\hline This & Frequency & Percentage \\
\hline Explanation & 28 & 16,9 \\
Interpretation & 23 & 13,9 \\
Circumstance & 14 & 8,4 \\
Background & 3 & 1,8 \\
Hypothetical & 10 & 6,0 \\
Evidence & 4 & 2,4 \\
Reason & 10 & 6,0 \\
Evaluation & 14 & 8,4 \\
Elaboration & 6 & 3,6 \\
Concession & 2 & 1,2 \\
Result & 27 & 16,3 \\
Means & 5 & 3,0 \\
Addition & 2 & 1,2 \\
Textual & 4 & 2,4 \\
Organization & & \\
Sequence & 4 & 2,4 \\
Justification & 8 & 4,8 \\
Summarization & 2 & 1,2 \\
\hline Total & 166 & 100 \\
\hline
\end{tabular}

Table 2. Rhetorical relations with that

\begin{tabular}{lrr}
\hline That & Frequency & Percentage \\
\hline List & 3 & 9,4 \\
Antithesis & 1 & 3,1 \\
Contrast & 8 & 25 \\
Condition & 6 & 18,8 \\
Addition & 2 & 6,3 \\
\hline Total & 32 & 100 \\
\hline
\end{tabular}

Excerpt (4) further illustrates the contrasting use of this and that. In (4a) this refers to Mai's educational strategy and is used in a proposition that establishes 
a 'circumstance' rhetorical relation, while that in (4c) introduces a new item in a 'list' relation regarding Mai's role as a teacher - that is, it signals that the writer is shifting to a new discourse unit. ${ }^{2}$

(4) (a) Mai says, "When my students behave badly, I am willing to tell them that they are wrong and that they should do this or that." (b) In doing this Mai did not 'lead' her students or force her ideas on them, but she still fulfilled the responsibility of a teacher who is socially expected to educate students. (c) More than that, Mai was a 'facilitator' in a more extensive way, not just ways. (d) This 2 can make the West think of the East as having no Western qualities.

These analyses show that RST can shed light on the pragmatics of demonstratives both as referring acts and their role in connecting the informative content to the intentional structure of the discourse. In relevance-theoretic terms then, they are like "discourse connectives", which are procedural lexical items giving instructions about how to develop the representation of utterances (Blakemore, 1992, p. 148). Thus, in their referring function, demonstratives have no semantic content but simply point to syntactic and pragmatic discourse entities (e.g., clauses, sentences, paragraphs, speech acts, etc.), but in terms of their communicative intentions, they place constraints on the interpretation of the rhetorical structure of the discourse and may signal propositional attitudes (i.e., what Cornish $(2001$, p. 297) refers to as the "modal" properties of the deictic pronouns).

We believe that the dual procedural meaning of discourse deictic pronouns, coupled with the fact that seemingly equivalent lexical items across languages may have non-overlapping pragmatic features, make their use in L2 systems a complex task.

In the following section we propose that the referring and intentional functions of $i t$, this and that can be captured with the concepts of basic-level and higher-level explicatures in Relevance Theory (hereafter RT).

\section{3 'It', 'This' and 'That' in RT and Explicatures}

RT would describe demonstratives as procedural lexical items. Similar to most pronouns, demonstratives make manifest to the addressee that the intended

\footnotetext{
${ }^{2}$ We should note that the referents of this and that may be ambiguous due to varying processing of the intentional structure of texts (Webber 1991). Notwithstanding this limitation, Taboada and Mann (2005: 443-4) report "highly consistent and reproducible" analyses of texts in a variety of studies.
} 
referents are retrievable from the discourse. They do not have fully developed propositional form, that is, truth-conditional content, since the intended referent can only be identified by the enrichment of the linguistic form with contextual information (Wilson \& Sperber, 1993). To clarify the sense in which demonstratives are procedural lexical items, we will summarize aspects of RT, focusing on the notion of explicatures.

The major tenet in RT is that the human mind is geared toward the "maximisation of relevance." In communication, this propensity is defined as the Communicative Principle of Relevance, which reads as "Every act of ostensive communication communicates a presumption of its own optimal relevance" (Sperber \& Wilson, 1995, p. 260). Optimal relevance in the case of the demonstratives, then, would mean that the speaker should employ a linguistic form that effectively activates and brings a discourse entity within the addressee's focus of attention in terms of its relations to the unfolding discourse.

RT proposes that utterance interpretation involves the processing two kinds of cognitive entities: (non-)propositional linguistic forms, which have logical properties, and propositional entities. Linguistic forms feed into utterance interpretation as "assumption schemas" (Sperber \& Wilson 1995, p. 73), which are enriched into propositional forms, that is, basic-level and higher-level explicatures, through integration with contextual information (Wilson \& Sperber, 1993; 2002).

Sperber and Wilson (1995) define a basic-level explicature as an explicitly communicated assumption: "An assumption communicated by an utterance $U$ is explicit if and only if it is a development of a logical form encoded by $U$ " (p.182). For example, the assumption schema of the pronoun in 'She signed the letter' logically excludes 'no one' and 'John' as an intended referent. The enrichment of this schema into a referent, let us say Jane, yields the basic-level explicature 'Jane signed the letter'. In the same manner, the assumption schema for a demonstrative is like an instruction for comprehenders to bring to their attention an entity that is identifiable in the discourse.

Wilson and Sperber (2002) later introduce the concept of higher-level explicatures. These are "obtained by embedding the proposition expressed under an appropriate speech-act or propositional-attitude description" (p. 272). Samples of (non-)linguistic stimuli constraining the generation of higher-level explicatures include linguistic forms such as sentential adverbials and higherlevel descriptions - tone of voice, gestures, etc. The notion of higher-level explicatures is significant for the pragmatics of discourse deictics as it accommodates the role of demonstratives in the higher-level processing of discourse units - which as RST shows, involves the interface of the attentional state and the intentional structure (i.e. the communicative intention) of discourse.

We propose that discourse deictic it, this and that contribute both to the derivation of explicatures and to the intentional structure of discourse. Together 
with the semantic content of utterances, they function as pointers to the relations between discourse units (e.g., a clause and a verb phrase) and the propositional attitude of speakers (e.g., interpretation, evaluation, antithesis). For example, this in unit (2) of the excerpt in Figure 1 - repeated below as (5) - instructs the reader that the intended referent is the noun clause in unit (1). This is part of the enrichment of the basic-level explicature of unit (2), which may be rendered as 'It's being impossible to... does not mean that in real-life...':

(5) 1. The problem for researchers is that it is impossible to get inside people's heads and observe how their vocabularies are organized, and how this organization interacts with vocabulary loss.

2. This means that in real-life we do not have any real alternatives to the approaches reported in attrition literature.

3 . However, that does not mean that it is impossible for us to explore the way attrition might work in a lexical network.

With the use of the verb 'mean', this contributes to affecting an 'interpretation' relation, which is a higher-level explicature since it expands on the implications of the impossibility of getting 'inside people's heads'. In other words, this contributes to the argumentation in the article regarding ways of researching people's lexicon.

While that in unit (3) of the same excerpt also instructs the reader to pick up the noun clause in the previous unit ('that in real-life .... in attrition literature'), it is used in an 'antithesis' relation, which functions toward effecting an acceptance of a predication. Along with the presence of however, that contributes to the inferencing of this propositional attitude. In other words, that contributes to the higher-level explicature enrichment of the utterance. (Notice that $i$ cannot replace this or that in units 2 and 3, and neither are this and that interchangeable.) In this manner, the demonstratives affect the derivation of both the basic-level and the higher-level explicatures of the utterance. Given the preferential use of this and that in Çokal's (2005) corpus, it appears to be the case that the rhetorical relations favour one or the other demonstrative in written discourse.

In contrast to the procedural meanings of this and that, we maintain that it at least in the way it appears in the data described in a number of studies (e.g., Webber, 1991) - contributes primarily to the basic-level explicature of an utterance since it points to a discourse entity that has already been syntactically nominalised and topicalised in the current text location. It indicates that little cognitive effort is needed to access its referent (Brennnan, 1995). However, the item does not make the intended referent irrelevant to the discourse, since it contributes to a continued rhetorical relation and/or reference to the discourse 
entity. Observe, for example, the topic-comment relation in excerpt (3) repeated as (6) - where it is used in the additional comment in (6d):

(6) (a) It's always been presumed that when the glaciers receded, the area got very hot. (b) The Folsom men couldn't adapt, and they died out. (c) That's what is supposed to have happened. (d) It's the textbook dogma.

We therefore find the description of the pragmatic function of it as signalling "low focus" (Strauss, 2002, p. 135) to be rather misleading in the context of understanding cognitive processing, since it seems to suggest that what is not in focus is not attended to. On the contrary, as our L2 data too will reveal, it may very well be the optimal marker for learners within their current pragmalinguistic competence regarding pointing acts, if they think that what is within their attentional focus is also within that of the reader. Furthermore, addressers are continually under the pressure of accomplishing multiple tasks: While they monitor their thoughts at the conceptualisation stage, they simultaneously plan the linguistic realisation of other thoughts (Levelt, 1989, p. 108-110). In this respect, a discourse entity that is information-wise relevant for the speaker at the conceptualisation stage (and thus possibly salient in memory) may become communicatively relevant. This may account for referring acts employing it at stages in the discourse where s/he is processing links between discourse units.

To sum up the discussion, we propose that this and that instruct the reader/addressee to expend greater processing effort in integrating information in the current text location with previous discourse units. This is because the demonstratives point toward non-nominal syntactic structures and (large) discourse units. They therefore entail and signal greater processing effort (see Çokal et al., 2017 for processing differences between it and this).

The implications of this discussion for discourse deictics is that they involve implicit pragmatic procedural knowledge and are relatively automatic processes, which are unavailable to consciousness in real-time communication (Skehan, 1996). How far L2 learners work with pragmatic procedures in the case of demonstratives is a question that needs further research (see Çokal et al., 2018 for Turkish L2 learners' online processing for it and this). Notwithstanding this gap, we will look into the data at hand to glean what procedures may underlie the distribution of the expressions.

\subsection{Previous Studies on L2 Demonstrative System}

Though L2 writers frequently use demonstratives/discourse deixis in written discourse, there have been few studies of L2 learners' interlanguage pragmatics of these expressions. Recent studies have utilized an eye-tracker to investigate L2 learners' online processing strategies of these expressions (Çokal, 2012; Çokal, Sturt, \& Ferreira, 2018; Ellert, 2013; Wilson, 2009). 
Previously, L2 speakers were found to employ different processing strategies from L1 (i.e., native speakers) in processing of anaphors and demonstratives (Cunnings, 2017; Cunnings, Fotiadou, \& Tsimpli, 2017). Such L2 processing differences may not be related to similarities or differences in anaphor systems. Even though Dutch and German have typologically close anaphora systems, low proficiency Dutch learners did not have asymmetrical antecedent preferences for personal pronouns or demonstratives (Ellert, 2013). Since English and German have different parameters for pronouns and demonstratives, advanced non-native speakers of German show either no clear preference regarding the referents of demonstratives or have a weak preference for a subject reference over an object reference for both pronouns/demonstratives (Wilson, 2009).

While Turkish and English have different demonstrative systems, results show L2 speakers (i.e., higher proficiency L2 groups/4 ${ }^{\text {th }}$ year Middle East Technical University [METU] students) displayed nativelike sensitivity to antecedents while using it and this in sentence completion experiment, but this sensitivity was not replicated in an online eye-tracking reading experiment, which revealed limitations in L2 speakers' use of information and poor performance in the use of pragmatic changes in context to track the antecedents of $i$ and this (Çokal et al., 2018).

Studies on L2 demonstrative system have explored whether L2 learners are aware of personal pronouns/anaphors and if demonstratives bring different entities into focus. However, studies have not explored: (a) the interlanguage pragmatics of these expressions across different proficiency levels; (b) inappropriate use of this and that with respect to the derivation of higher-level explicatures (e.g., modality distinctions/rhetorical relations); (c) whether L2 learners maintain optimal relevance in identifying discourse entities in written discourse, and (d) what default anaphoric expression is a high and low level interlanguage system.

\subsection{Predictions of the Study}

Based on the preceding review of literature, our hypotheses regarding L2 use of the discourse deictics are the following. L2 learners will:

1. maintain optimal relevance in pointing to discourse entities;

2. use this as the default demonstrative in pointing to a discourse entity that has not been topicalised;

3. will use it as a discourse deictic under non-optimal processing of pointing acts when the discourse entity is highly accessible in memory;

4. display inappropriate use of this and that with respect to the derivation of higher-level explicatures. 
The first hypothesis derives from our assumption that the Communicative Principle of Relevance is a universal feature of communication. The second hypothesis is based on the reasoning that when a discourse entity is accessible in memory, learners will use this once they have acquired the procedural constraint that this topicalises discourse entities. Statement (3) is grounded on findings in experimental studies which note that less marked pronominals are used when a referent's trace is available in memory (e.g., Brennan 1995). We expect inappropriate use under hypothesis 4 since learners may not be aware of the rhetorical relations in which the demonstratives occur. The participants in this study do not receive explicit or substantial implicit instruction on the pragmatics of the demonstratives. However, even if they are aware of them, they may not be able to attend to the inter-connection during online processing. A related factor is that appropriate discourse deictic use of demonstratives is expected to be a late development in IL pragmalinguistic competence (see Niimura \& Hayashi, 1996; p. 818 passim).

\section{Methodology}

In the following sections we describe the data collected for this study and the major findings.

\subsection{Participants and Data Collection}

The study's participants were Turkish non-native English-speaking students at METU. Participants were unaware of the study's purpose and completed consent forms prior to taking part in the study.

We collected two sets of data for the study. In the first set, first and fourth year students enrolled in the English Language Teaching Department at METU wrote an argumentative essay. A small number of essays were also written by second-year students. However, in order to comprehensively view L2 learners' interlanguage pragmatics of the expressions, we did not exclude $2^{\text {nd }}$ year student essays from the analysis.

The topic of the argumentative essay was "The Medium of Instruction in Educational Institutions." We assumed students would not experience world knowledge or vocabulary deficits in the area and that they would have developed their own positions on the topic.

The second data set comprised a fill-in-the-blank with a multiple-choice (the alternatives with $i t$, this and that), consisting mostly of excerpts from articles in academic journals devoted to applied linguistics. Fill-in-the-blank test excerpts were taken from Çokal's (2005) study. While selecting, we paid attention to the frequency with which rhetorical relations/model properties of $i$, this and that are 
used in Cornish (2001) and Çokal (2005) findings. For example, we selected an excerpt in which that was used appropriately in antithesis/contrast relations (See Appendix A for the fill-in-the-blank task.). Care was also taken to avoid specialised vocabulary or content. In order to trace earlier stages in the use of the demonstratives, the test was administered to pre- and upper-intermediate students in the University Preparatory School, as well as $1^{\text {st }}, 2^{\text {nd }}$, and $4^{\text {th }}$-year students in the ELT Department. Data types are shown in Table 3:

Table 3. Data types

\begin{tabular}{|c|c|c|c|}
\hline Data Type & 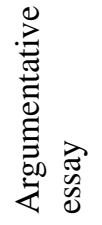 & 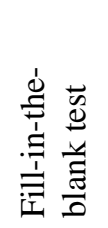 & 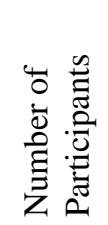 \\
\hline Pre-intermediate & & $\sqrt{ }$ & 70 \\
\hline Upper-intermediate & & $\sqrt{ }$ & 44 \\
\hline $1^{\text {st }}$ year FLE & $\sqrt{ }$ & $\sqrt{ }$ & 81 \\
\hline $2^{\text {nd }}$ year FLE* & $\sqrt{ }$ & $\sqrt{ }$ & 59 \\
\hline $4^{\text {th }}$ year FLE & $\sqrt{ }$ & $\sqrt{ }$ & 63 \\
\hline Total & & & 317 \\
\hline
\end{tabular}

The students in the ELT Department receive instruction in writing skills in four courses. The first-year students were taking their second course at the time the argumentative essays were written. As mentioned in Section 2.3, they do not receive explicit instruction on the discourse deictic markers, except in an indirect manner in reading activities or in feedback on written material. Such activities may include questions about the referent of the demonstratives. It was expected, however, that the $2^{\text {nd }}$ years would perform better due to the recency effect of having completed three proficiency courses. We need to note, though, that the study is limited in terms of grouping according to proficiency since we assumed that increased exposure would mean better performance.

\subsection{Data Analysis}

The essays were coded for use of it, this and that with respect to appropriateness and the rhetorical relation in which the expressions occur. For the test, we made 
cross-tabulations for all the items. We will first summarise the results of the test and concentrate only on the $1^{\text {st }}$ and $4^{\text {th }}$ year essays in Section 4.1 .

\section{Test Results}

The test revealed significant differences in the use of $i$, this and that between the pre-intermediate and the $1-4^{\text {th }}$ year students on some of the test items. Tables $4 \mathrm{a}$ and $4 \mathrm{~b}$ present the percentage of correct responses in each group.

Table 4a. Percentage of correct responses on 'this' in each group

\begin{tabular}{|c|c|c|c|c|c|c|c|}
\hline & & & & This & & & \\
\hline Item number & $2 *$ & $3 *$ & $5^{*}$ & 6 & 9 & $11 *$ & $12 *$ \\
\hline \multicolumn{8}{|l|}{ Year } \\
\hline Pre-intermediate & 46.5 & 38.0 & 25.4 & 23.9 & 26.8 & 15.5 & 38.0 \\
\hline Upper intermediate & 29.1 & 56.4 & 40.0 & 49.1 & 38.2 & 41.8 & 47.3 \\
\hline $1^{\text {st }}$ & 42.5 & 71.3 & 47.5 & 40.0 & 35.0 & 38.8 & 47.5 \\
\hline $2^{\text {nd }}$ & 57.5 & 65.0 & 62.5 & 32.5 & 52.5 & 52.5 & 52.5 \\
\hline $4^{\text {th }}$ & 32.8 & 84.4 & 39.1 & 34.4 & 45.3 & 43.8 & 53.1 \\
\hline
\end{tabular}

* On these items, Pearson Chi-Square tests revealed significant inter-group differences.

Table 4b. Percentage of correct responses on 'that' in each group

\begin{tabular}{lcccccc}
\hline & \multicolumn{7}{c}{ That } \\
\hline Item number & $1 *$ & $4 *$ & 7 & $8^{*}$ & $10^{*}$ & 13 \\
\hline Year & & & & & & \\
\cline { 1 - 6 } Pre-intermediate & 14.1 & 50.7 & 19.7 & 57.7 & 23.9 & 14.1 \\
Upper-intermediate & 29.1 & 49.1 & 18.2 & 58.2 & 32.7 & 25.5 \\
1st & 41.3 & 61.3 & 11.3 & 48.8 & 75.0 & 22.5 \\
2nd & $\mathbf{5 7 . 5}$ & $\mathbf{7 5 . 0}$ & 12.5 & 37.5 & $\mathbf{8 0 . 0}$ & 40.0 \\
4th & 39.1 & 71.9 & 9.4 & 43.8 & 59.4 & 18.8 \\
\hline
\end{tabular}

* On these items, Pearson Chi-Square tests revealed significant inter-group differences.

We first draw attention to the fact that overall, $2^{\text {nd }}$-year students performed better on the test than other groups (see Tables $4 \mathrm{a} / 4 \mathrm{~b}$ ). We would explain this as the 
effect of practice in the proficiency courses. But as noted by Blagoeva (2004), appropriate use of demonstrative reference remains problematic at advanced levels of proficiency. Below we will refer to only those items where there were significant differences in performance.

Table 5. Percentage of incorrect responses for 'it' in each group

\begin{tabular}{|c|c|c|c|c|c|c|c|}
\hline $\begin{array}{l}\text { Item number \& } \\
\text { appropriate } \\
\text { referential expression }\end{array}$ & $\begin{array}{l}\text { (1) } \\
\text { That }\end{array}$ & $\begin{array}{l}\text { (2) } \\
\text { This }\end{array}$ & $\begin{array}{l}\text { (3) } \\
\text { This }\end{array}$ & $\begin{array}{l}\text { (4) } \\
\text { That }\end{array}$ & $\begin{array}{l}\text { (5) } \\
\text { This }\end{array}$ & $\begin{array}{c}(6) \\
\text { This }\end{array}$ & $\begin{array}{l}\text { (7) } \\
\text { That }\end{array}$ \\
\hline \multicolumn{8}{|l|}{ Year } \\
\hline Pre-intermediate & 69.0 & 40.8 & 16.9 & 23.9 & 57.7 & 67.6 & 52.1 \\
\hline Upper-intermediate & 14.5 & 57.8 & 7.3 & 10.9 & 41.8 & 47.3 & 56.4 \\
\hline $1^{\text {st }}$ & 22.5 & 53.8 & 1.3 & 2.5 & 37.5 & 50.0 & 68.8 \\
\hline $2^{\text {nd }}$ & 12.5 & 30.0 & 0.0 & 0.0 & 22.5 & 52.5 & 72.5 \\
\hline $4^{\text {th }}$ & 25.0 & 57.8 & 3.1 & 6.3 & 31.3 & 51.6 & 75.0 \\
\hline Item number & $\begin{array}{l}(8) \\
\text { That }\end{array}$ & $\begin{array}{c}(9) \\
\text { This } \\
\end{array}$ & $\begin{array}{l}\text { (10) } \\
\text { That }\end{array}$ & $\begin{array}{l}\text { (11) } \\
\text { This }\end{array}$ & $\begin{array}{l}\text { (12) } \\
\text { This }\end{array}$ & $\begin{array}{l}\text { (13) } \\
\text { That }\end{array}$ & \\
\hline \multicolumn{8}{|l|}{ Year } \\
\hline Pre-intermediate & 14.1 & 60.6 & 28.2 & 66.2 & 33.8 & 46.5 & \\
\hline Upper-intermediate & 9.1 & 58.2 & 36.4 & 50.9 & 34.5 & 34.5 & \\
\hline $1^{\text {st }}$ & 7.5 & 62.5 & 3.8 & 55.0 & 38.8 & 40.0 & \\
\hline $2^{\text {nd }}$ & 2.5 & 40.0 & 5.0 & 42.5 & 37.5 & 37.5 & \\
\hline $4^{\text {th }}$ & 4.7 & 48.4 & 12.5 & 48.4 & 34.4 & 40.6 & \\
\hline
\end{tabular}


Table 6. Percentage of incorrect responses for 'this' where 'that' is appropriate

\begin{tabular}{lcccccc}
\hline $\begin{array}{l}\text { Item \& } \\
\text { appropriate } \\
\text { referential expression }\end{array}$ & $\begin{array}{c}(1) \\
\text { That }\end{array}$ & $\begin{array}{c}(4) \\
\text { That }\end{array}$ & $\begin{array}{c}(7) \\
\text { That }\end{array}$ & $\begin{array}{c}(8) \\
\text { That }\end{array}$ & $\begin{array}{c}(10) \\
\text { That }\end{array}$ & $\begin{array}{c}(13) \\
\text { That }\end{array}$ \\
\hline Year & & & & & & \\
\hline Pre-intermediate & 16.9 & 25.4 & 28.2 & 26.8 & 47.9 & 46.5 \\
Upper-intermediate & 56.4 & 40.0 & 25.5 & 32.7 & 30.9 & 30.9 \\
$1^{\text {st }}$ & 36.3 & 35.0 & 20.0 & 43.8 & 20.0 & 37.5 \\
$2^{\text {nd }}$ & 30.0 & 22.5 & 15.0 & 60.0 & 15.0 & 40.0 \\
$4^{\text {th }}$ & 35.9 & 21.9 & 15.6 & 51.6 & 28.1 & 29.7 \\
\hline
\end{tabular}

Pre-intermediate students consistently use it instead of this or that (see Table 5). The text in item (1) - given as 8 below - is one of the contexts in which the lower level proficiency group predominantly used it:

(8) I am not saying that there are no native speakers of English any more- if by native speakers we mean persons who were born and brought up in monolingual homes with no contact with other languages. Indeed, that would be an illogical thing to say.

It seems lower-level learners are not aware $\underline{i t}$ requires a NP referent. In addition, sentence structure may have been interpreted as an empty subject $\underline{i t}$. This variation between NP reference and empty subject use of it may indicate an unstable IL grammar. For example, in item 12, given as (9) below, the use of this is preferred to it, since the writer's opinion about the previous proposition "the higher number of vocabulary items in the course book is similar to written texts rather than spoken texts". In addition, this refers to the proposition in the previous clause rather than a NP. However, lower-proficiency students preferred it to this because the clause-initial position in the coordinated clause might be interpreted as empty subject-it:

(9) The higher number of vocabulary items found in course book texts is more similar to written texts than spoken texts, and (12) .......is not surprising since... 
The inappropriate use of this (where that is required) seems to diminish with proficiency (see Table 6). However, in item (8) fourth and second-year students performed poorly compared to upper and pre intermediate students (see Table 6). Item 8 involved the case of the fairly formulaic expression: 'Having said that, ...'. The result from upper and pre-intermediate students, here, may be due to formulaicity or the perception of that as a complementizer as in 'It is said that...'.

\subsection{Essay Writing}

As mentioned in the foregoing section, a major difference between the $1^{\text {st }}$ and $4^{\text {th }}$ year essays is the smaller number of tokens of this and that in the latter group. A survey of the $4^{\text {th }}$ year essays revealed higher use of transitional expressions and explicit explanation such as 'As it is understood from the example...' (see excerpt 10 below). This suggests that the $4^{\text {th }}$ year essays are characterised more by explicit communication. The $1^{\text {st }}$ year essays, however, rely more on the inferencing of the intended referents through explicature derivation. For example, a structure such as 'This shows that...' requires the enrichment of the basic-level explicature by picking up a discourse entity in the previous part of the discourse. Excerpt (10), written by a $4^{\text {th }}$ year student, illustrates a case of explicit communication. (We have marked the sentential themes and connectives in bold and have deleted parts of sentences to save space.):

(10) Although I don't have any certain ideas about the practice of using a foreign language as the medium of education in schools and universities, I find it inappropriate .... Of course, there are some critics who claim that in order to reach much more sources it is necessary to know a foreign language .... For instance, it is a fact that there are lots of German mathematicians and physicians, but we still try to teach .... Moreover, the effectiveness of the lessons should be questioned. ... However, she cannot make them participate in the lesson... Therefore, studying in English is a nightmare for them. As it is understood from the example students cannot be a proficient neither in their English nor in their areas.

Comparing (10) with a portion of an essay written by a $1^{\text {st }}$ year student (see excerpt 11), we observe that links between sentences are established with the use of it or this. As will be observed in the paragraph, a frequent problem that the learners experience is making the referent mutually manifest to the reader. The intended referents are in bold: 
(11) There is another point about using foreign language that is students may not understand everything the instructor says. This means that ...., they cannot understand some points because of foreign language. $\mathrm{It}_{\mathbf{1}}$ may be because of .... May be students' lack of hearing or may be his lack of attention. $\boldsymbol{I t}_{\mathbf{2}}$ is gain a big problem and ....

We now turn to a more detailed discussion of the use of the expressions.

\subsection{Use of 'It' in the Essays}

$1^{\text {st }}, 2^{\text {nd }}$, and $4^{\text {th }}$ year students used it inappropriately to refer to a previous part of the discourse. Some were obscure and had no antecedent (see $i t_{2}$ in sample 12), and others inappropriately referred to the proposition in the previous unit or to a larger discourse segment. It was also observed that the difficulty of making the referent manifest to the reader persists at these levels. Table 7 presents the type of inappropriate use of $i$, and Table 8 lists the rhetorical relations in which it occurs in the essays:

Table 7. Inappropriate use of 'it' in the essays

\begin{tabular}{|c|c|c|c|c|c|c|c|c|c|c|c|}
\hline Year & $\begin{array}{l}\stackrel{2}{>} \\
\stackrel{0}{E}\end{array}$ & 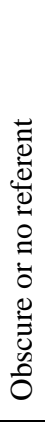 & 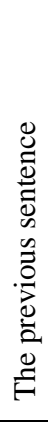 & 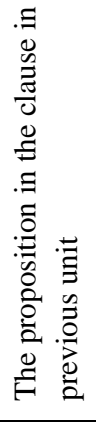 & 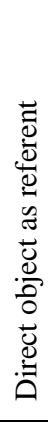 & 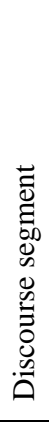 & 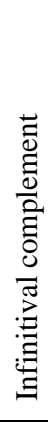 & TO & & 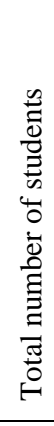 & 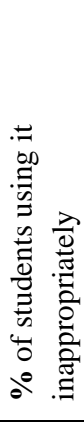 \\
\hline 1 & 6 & 7 & 4 & 3 & 1 & 1 & -- & $\mathrm{n}=$ & 22 & 59 & 37 \\
\hline 2 & 1 & 5 & -- & 1 & -- & -- & -- & $\mathrm{n}=$ & 7 & 15 & 46 \\
\hline 4 & 6 & 4 & 8 & 3 & -- & 1 & 1 & $\mathrm{n}=$ & 23 & 63 & 37 \\
\hline
\end{tabular}


Table 8. Use of 'it' and rhetorical relations

\begin{tabular}{|c|c|c|c|c|c|c|c|c|c|c|c|c|c|c|c|c|c|}
\hline 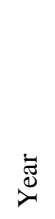 & 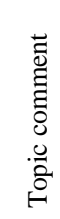 & 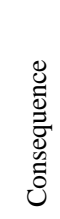 & $\begin{array}{l}\overrightarrow{\tilde{E}} \\
\stackrel{\tilde{\Xi}}{0} \\
\tilde{U}\end{array}$ & 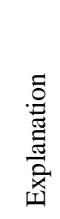 & 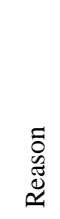 & 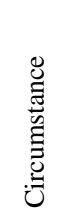 & $\frac{\vec{n}}{3}$ & 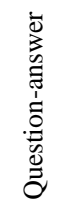 & $\begin{array}{l}\vec{\Xi} \\
\stackrel{\Xi}{\Xi} \\
\stackrel{\Xi}{\Xi}\end{array}$ & $\begin{array}{l}\infty \\
\sum_{\tilde{E}}^{ \pm}\end{array}$ & 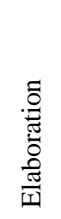 & 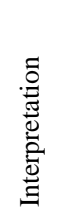 & 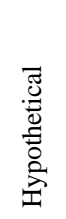 & 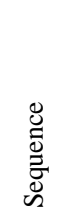 & 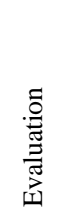 & & 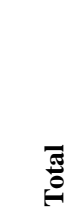 \\
\hline 1 & 6 & 6 & 6 & 2 & 2 & -- & -- & 1 & 1 & 1 & 1 & 1 & -- & 1 & -- & $\mathrm{n}=$ & 28 \\
\hline 2 & 5 & -- & -- & -- & -- & -- & -- & -- & -- & -- & -- & 2 & -- & -- & -- & $\mathrm{n}=$ & 7 \\
\hline 4 & 1 & 5 & 1 & 3 & 3 & 5 & 1 & -- & 1 & -- & -- & -- & 1 & -- & 2 & $\mathrm{n}=$ & 23 \\
\hline
\end{tabular}

Table 8 shows that both $1^{\text {st }}$ and $4^{\text {th }}$ year students, it seems to fulfil the function of this especially in 'consequence' relations, while $1^{\text {st }}$ and $2^{\text {nd }}$ year students, it replaces that in 'topic-comment' and 'contrast' relations. Samples (12) and (13) illustrate the inappropriate use of it. (The phrases or clauses in bold mark the intended referents and the rhetorical relations are indicated in parentheses.):

(12) the inappropriate use of it instead of this:

For example, a Turkish student can learn a subject .... in Turkish. It is because .... ( $1^{\text {st }}$ year; reason relation $)$

(13) the inappropriate use of it instead of that:

When we think why some schools and universities use foreign language in education, we may encounter the aim of teaching students English easily. However, it is not the case in reality ( $1^{\text {st }}$ year; contrast relation)

\subsection{Use of 'This' in the Essays}

As in the case of the $1^{\text {st }}$ year students, obscurity or lack of referent remains as to be a problem in maintaining coherence (see Table 9).

A significant difference between the groups is that although the $4^{\text {th }}$ year students still have problems using the demonstrative appropriately in indicating propositional attitude (i.e., using this where that is appropriate), they do not make mistakes in use of this in its expected rhetorical relation. Since rhetorical relations are closely intertwined with the intentional properties of the pronouns, it is safe to conclude that acquisition of the intentional properties of the demonstratives is a later developmental phenomenon. Tables 9 and 10 summarise instances of the inappropriate use of this in the essays and the rhetorical relations in which the tokens occur. 
Table 9. Inappropriate use of 'this'

\begin{tabular}{|c|c|c|c|c|c|c|c|c|c|c|c|}
\hline Year & 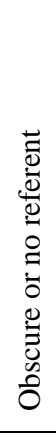 & 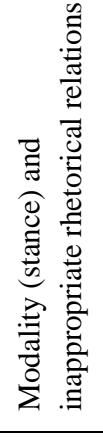 & 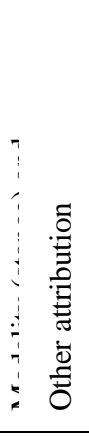 & 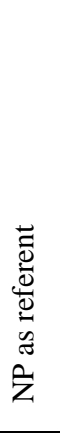 & 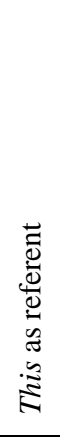 & 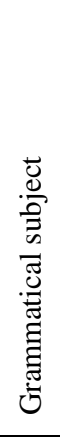 & 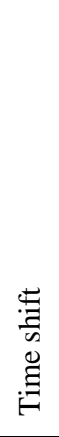 & & & 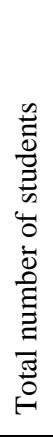 & 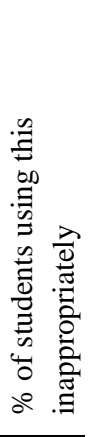 \\
\hline 1 & 14 & 6 & 1 & 1 & --- & 1 & 3 & $\mathrm{n}=$ & 26 & 59 & 44 \\
\hline 2 & 4 & --- & -- & -- & --- & --- & --- & $\mathrm{n}=$ & 4 & 15 & 26 \\
\hline 4 & 8 & 4 & -- & -- & 1 & -- & -- & $\mathrm{n}=$ & 13 & 63 & 21 \\
\hline
\end{tabular}

Table 10. Use of 'this' and rhetorical relations

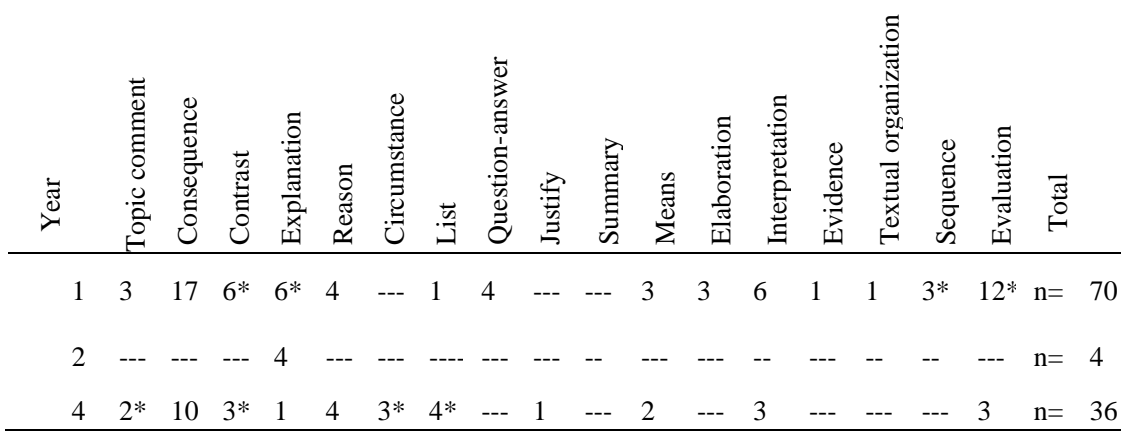

* Indicates usage in the inappropriate rhetorical relation or lack of clarity in making the referent mutually manifest.

Table 10 reveals that $1^{\text {st }}$ year students make inappropriate use of this mostly in 'evaluation', 'contrast' and 'explanation' relations. In the case of the $4^{\text {th }}$ year students, the use of this occurs mostly in 'contrast, 'explanation', 'circumstance' and 'topic-comment' relations. As mentioned in Section 2.2, these are sites for that in academic discourse.

Excerpts (14) and (15) illustrate cases where that is prevalent in academic discourse: 
(14) He or she will not be able to find exact words for a term in English. Besides this, the students in high school do not have so advanced English as the teacher. ( $1^{\text {st }}$ year; list $)$

(15) Some argue that education in a foreign language increase the knowledge of that language. By being in the same environment where that language is spoken, one can make his language level further. This may be true to some extent, but ...( $1^{\text {st }}$ year; evaluation $)$

In sample (14), the writer moves on to a new 'list' item in a discourse topic (i.e. problems concerning the medium of instruction). In such cases, that is the preferred demonstrative. Sample (15) effects a 'contrast' relation, which again is the domain of that (see Table 2 in Section 2.2).

\subsection{Use of 'That' in the Essays}

A difference between the $1^{\text {st }}, 2^{\text {nd }}$, and $4^{\text {th }}$ year essays is that there is a higher number of tokens of that in the first year group. As mentioned in Section 3.4, the $1^{\text {st }}$ year essays show greater context-boundness in establishing links between discourse units. This, we believe, accounts for the higher number of tokens of that in their essays.

Twelve of the 22 tokens of that in the $1^{\text {st }}$ year essays were found to be inappropriate due to use in the wrong formulaic expression, in the inappropriate rhetorical relation, or in stretches of text where there is a continuation of the topic of the discourse segment. In the $4^{\text {th }}$ year essays, there were only seven tokens of that, four of which were inappropriate due to obscurity or lack of referent. Inappropriate uses of that were found only in $2^{\text {nd }}$-year essays.

Comparing the use of this in units where that should be used in the multiplechoice test, we $4^{\text {th }}$ year students showed lower frequencies of inappropriate use of this on most of the items. It appears advanced learners are aware of modal distinctions between this and that, even if only on the recognitional level,

Excerpt (16) illustrates a case of the use of that where this is grammatical:

(16) For just a moment think about that: You are a student and a Turk... you manage to communicate with another language .... ( $1^{\text {st }}$ year; textual organisation)

As stated in the literature, that implies a shared attentional focus on a discourse entity (see, Cornish, 2001, p. 312-313), whereas this marks the speaker's attentional focus and shift the speaker's focus to the upcoming text. Sample (16) shows that students may experience difficulty in taking the point of view of the 
reader, for whom the informative content of the intended referent of the demonstrative has not yet become manifest.

Tables 11 and 12 lists the contexts where that was used inappropriately and in the rhetorical relations in which they occur.

Table 11. Inappropriate use of 'that'

\begin{tabular}{|c|c|c|c|c|c|c|c|c|c|c|c|}
\hline Year & 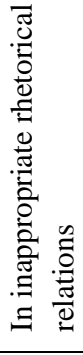 & 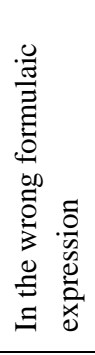 & 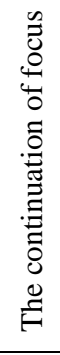 & $\begin{array}{l}0 \\
\stackrel{0}{0} \\
0\end{array}$ & 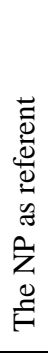 & 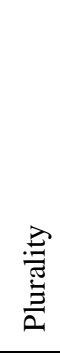 & 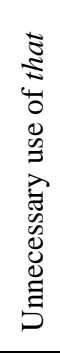 & & $\mathrm{AL}$ & 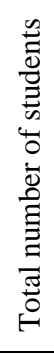 & 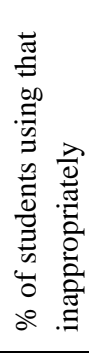 \\
\hline 1 & 4 & 3 & 3 & 3 & 1 & 1 & --- & $\mathrm{n}=$ & 15 & 59 & 25 \\
\hline 2 & --- & --- & --- & 2 & --- & --- & --- & $\mathrm{n}=$ & 2 & 15 & 13 \\
\hline 4 & 2 & --- & --- & 3 & --- & --- & --- & $\mathrm{n}=$ & 4 & 63 & 6 \\
\hline
\end{tabular}

Table 12. Use of 'that' in rhetorical relations

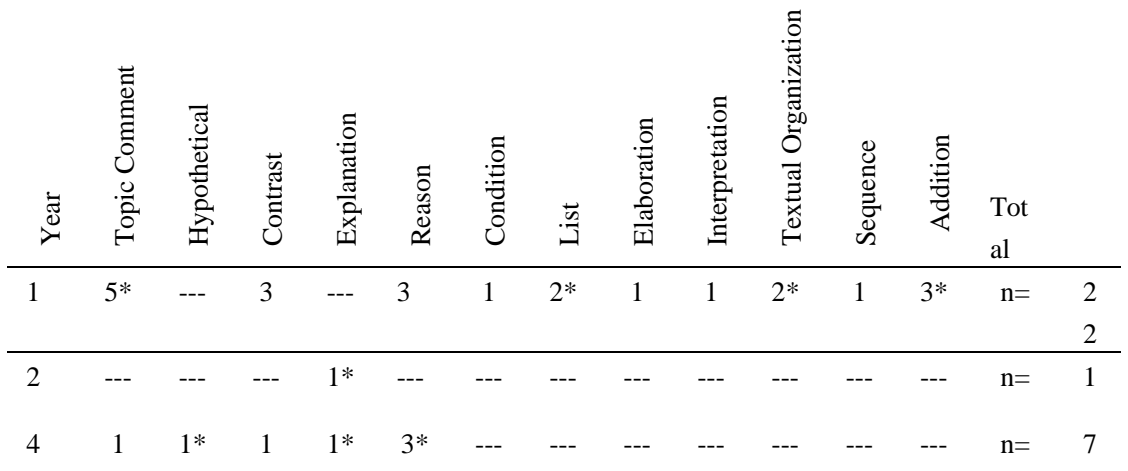

* indicates usage in the inappropriate rhetorical relation or lack of clarity in making the referent mutually manifest. 
The inappropriate use of that in the $1^{\text {st }}$ year essays concerns lack of clarity or referent even though they are used in the expected rhetorical relations. The few tokens of that in the $4^{\text {th }}$ year essays are used in the inappropriate rhetorical relation, which might suggest that the appropriate use of that is problematic even at later stages in acquisition (see, Blagoeva, 2004).

\section{The Pragmatics of IL Demonstratives}

Communication requires that transitions from topics be smooth and that the attentional foci of discourse be interactionally achieved between interlocutors. In this respect, demonstratives demand processing efficiency in referring to discourse entities. However, the results of the essay writing reveal that managing multiple goals is a difficult task and suggest that L2 writers may experience cognitive overload in tracking referents during the formulation of their thoughts. The main difficulty the present group of L2 writers - especially $1^{\text {st }}$-year students - have is making intended referents explicit to readers. Once a proposition is introduced in a previous unit, especially in the VP of a previous sentence, L2 writers seem to assume it is topicalised and mutually manifest to their readers. In such cases, while it is used by lower levels of proficiency and this is preferred by higher levels of proficiency.

As was mentioned in footnote 5, tokens of it in the essays at lowerproficiency levels and the inappropriate use of some tokens of that may be cases of pragmatic transfer from the Turkish deictic system. In addition, given that Niimura and Hayashi (1996) report similar tokens among Japanese L2 learners of English, the inappropriate use of it may be a universal feature of IL English.

Therefore, the IL discourse deictic demonstrative system observed in our data suggests the following sequence of appropriate use in written discourse:

$$
\text { it } \rightarrow \text { this } \rightarrow \text { that }
$$

Results from our fill-in-the-blank task also show pre-intermediate students use it instead of this and that. In addition, the overall higher percentage of appropriate use of this compared to that and the increase in the appropriate use of the demonstratives at higher test proficiency levels supports this sequence (See Tables $4 \mathrm{a}$ and $4 \mathrm{~b}$ ). It is possible sensitivity to the inter-relationship between the rhetorical relations and demonstratives is a late pragmalinguistic development and requires skills in maintaining global coherence and managing multiple perspectives in discourse. 


\section{Conclusion}

Our first hypothesis (i.e., that L2 learners will maintain optimal relevance in pointing to discourse entities) has not been totally supported, as learners often appear to be writing solely from their own perspective. This leads to more tokens

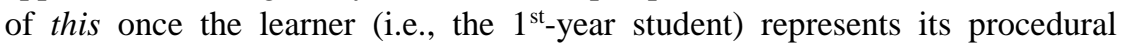
meaning as 'pick up a non-nominal discourse entity in the previous discourse unit'. The overall higher use of this/that in essays of $1^{\text {st }}$-year students may be explained as a difficulty in making critical assessments of the relative contribution of ideas to the argumentation.

Our second hypothesis (i.e. that learners will use this as the default discourse deictic demonstrative) has been borne out. The findings of the present study are slightly in contrast to those in Blagoeva (2004)'s comparative study on the use of this and that by L1 Bulgarian and L1 English learners of English. She reports that this is underused and that is overused by Bulgarian learners compared to L1 learners. Her explanation is grounded on teaching materials in the Bulgarian context, where the distinctions between the two demonstratives are overlooked. It is possible, though, that our results and those in Blagoeva's study stem in part from cross-linguistic differences in pronominal systems. Our data do not lend themselves to comparative analysis. Nevertheless, it is fairly clear that this is the default discourse deictic demonstrative - especially for $1^{\text {st }}$-year students (see Niimura \& Hayashi (1996, p. 823) for similar observations).

The third hypothesis that posited use of $i t$ as a discourse deictic is also valid for lower levels of proficiency. Its occurrence even at higher levels of proficiency also suggests that non-optimal processing of the Communicative Principle of Relevance leads L2 writers to use the pronoun rather than a demonstrative (see Table 7). The fourth hypothesis (i.e. that learners will display inappropriate use of this and that in the context of higher-level explicatures) concerns the interrelationship between types of rhetorical relations and demonstratives. We find that this hypothesis is largely supported (see Tables 1 and 2 and 8, 10 and 12). The study shows that the present group of learners are not totally aware of the propositional attitude indicating meaning of the demonstratives. For example, instead of that, $1^{\text {st }}$-year students use it for contrast relation. The $4^{\text {th }}$-year students performed better than $1^{\text {st }}$-year students in the use of this in appropriate rhetorical relations. However, use this instead of that in establishing contrast relation or topic comment. As noted above, the pragmatic function of that (i.e., modal aspects) might not be completely acquired at higher levels of proficiency.

Successful acquisition of the pragmatics of discourse deictics is arguably a difficult feat, and our view in this paper has relied on a deficit model of SLA (see Gass \& Selinker, 1994). We think that this is a justifiable position, as inappropriate use of deictics can lead to vague utterance meaning. As we have observed in Section 4.2, the erroneous use of $i t$, in both essay writing and fill-in the blank tasks, is especially problematic in maintaining referential and global 
coherence in learner writing at lower levels of proficiency. The IL features observed in the present data suggest a developmental continuum, with the possibility of stabilisation of the use of this and that, especially, toward nonstandard usage. Our personal teaching experience tells us that the modal use of that poses greater difficulties in the acquisition of written English, since we find it is used inappropriately - even by otherwise proficient speakers. As stated above, it emerges predominantly as a discourse deictic term at earlier stages in acquisition, to be replaced by this at later stages. However, the role of this and that in indicating propositional attitude remains problematic at advanced stages of acquisition (see Tables $10 \& 12$ ). Our results are consistent with onlineprocessing studies, which have also shown advanced stage problems in the use of anaphoric and demonstrative expressions (Çokal et al, 2018, Ellert, 2013; Wilson, 2009). This indicates L2 speakers poorly coordinate anaphoric choices regarding pragmatic and discursive information in context.

The findings imply that appropriate use of demonstratives requires learners to be able to maintain the perspective of both the writer and the reader in the flow of information. Difficulty in keeping track of what discourse entity is in attentional focus leads learners to refer to a discourse entity without first topicalising it. This is where we observe obscurity of reference in the essays.

In this study we have not made a comparative study of learner spoken and written discourse. We suggest that such comparative use would reveal whether the problems we have observed stem both from intralingual transfer of spoken to written style and from features special to online processing in written discourse. The transition from it to this as discourse deictics needs to be researched in other languages, too, to observe whether it is a development special to IL English in the Turkish context or whether it is a universal phenomenon. A further area to look into would be cross-linguistic IL data on the inter-relationship between demonstratives and rhetorical relations so as to investigate the impact of difficulties in information processing on use in a variety of contexts of writing.

The discussion on the distinctions between the basic-level and the higherlevel explicatures of discourse segments incorporating demonstratives suggests that acquiring their procedural meaning with respect to their contribution to higher-level explicatures is a complex task (see Moeschler (2004) on the significance of higher-level explicatures in misunderstanding). We suggest that awareness of the pragmatics of the demonstratives may be increased for the higher-level explicatures of the utterances in which the forms occur, since it is possible to provide explicit instruction on rhetorical relations/modal aspects. For example, the modal distinctions between this and that should be discussed in reading classes. L2 learners need to be aware of different propositional attitudes this and that contribute to. When an addresser agrees or supports a proposition, the use of this is preferred. On the other hand, when an addresser does not agree with the proposition, or wants to be maintain a distance from the idea, that is the 
word choice. Reading activities that require learners to identify the intended referents of the expressions could also require attention to be devoted to the unfolding intentional structure of the discourse by noting the rhetorical relations between discourse units.

\section{Kaynaklar}

Blagoeva, R. (2004). Demonstrative reference as a cohesive device in advanced learner writing: a corpus-based study. Language and Computers, 49(1), 297-307.

Blakemore, D. (1992). Understanding Utterances. Oxford: Blackwell.

Brennan, S. E. (1995). Centering attention in discourse. Language and Cognitive Processes, 10(2), 137-67.

Brown-Schmidt, S., Byron, D. K., \& Tanenhaus, M. K. (2005). Beyond salience: interpretation of personal and demonstrative pronouns. Journal of Memory and Language, 53, 292-313.

Carston, R. (2002). Linguistic meaning, communicated meaning, and cognitive pragmatics. Mind and Language, 17(1-2), 127-148.

Clahsen, H., \& Felser, C. (2006). Continuity and shallow structures in language processing. Applied Psycholinguistics, 27(1), 107-126.

Cornish, F. (2001). 'Modal' that as determiner and pronoun: The primacy of the cognitiveinteractive dimension. English Language and Linguistics, 5(2), 297-315.

Cornish, F. (2008). How indexicals function in texts: Discourse, text, and one neo-Gricean account of indexical reference. Journal of Pragmatics, 40, 997-1018.

Çokal, D. (2005). A contrastive analysis of the pronominal usages of this and that in academic written discourse. (Unpublished master's thesis). Middle East Technical University, Ankara, Turkey.

Çokal, D., Sturt, P., \& Ferreira, F. (2016). The processing of $i t$ and this in written narrative discourse. Discourse Processes, 272-289.

Çokal, D., Sturt, P., \& Ferreira, F. (2014). Deixis: This and that in written narrative discourse. Discourse Processes, 51, $201-229$.

Çokal, D., Sturt, P. \& Ferreira, F. (2018). L2 referent representation in processing and production. Proceedings of the $40^{\text {th }}$ Annual Conference of Cognitive Science Society.

Çokal, D. (2012). The Online and Offline Processing of This, That, and It by native speakers of English and by Turkish non-native speakers of English. (Unpublished doctoral dissertation). Middle East Technical University. Ankara.

Cunnings. I. (2017). Parsing and working memory in bilingual sentence processing. Bilingualism: Language and Cognition, 20(4), 659-678.

Cunnings. I., Fotiadou, G., \& Tsimpli, I. (2017). Anaphora resolution and reanalysis during L2 sentence processing. Studies in Second Language Acquisition, 39, 621-652.

Ellert, M. (2013). Resolving ambiguous pronouns in a second language: A visual-world eye-tracking study with Dutch learners of German. International Review of Applied Linguistics in Language Teaching, 51(2), 171- 197.

Diessel, H. (2006). Demonstratives, joint attention, and the emergence of grammar. Cognitive Linguistics, 17(4), 463-489. 
Ellis, N. (2005). At the interface: dynamic interactions of explicit and implicit language knowledge. SSLA, 27, 305-352.

Foster-Cohen, S. H. (2000). Review of Sperber, D. and Wilson, D. 1995: Relevance

Communication and Cognition. ( $2^{\text {nd }} \mathrm{ed}$.) Oxford: Blackwell. Second Language Research, 16(1), 77-92.

Gass, S., \& Selinker, L. (1994). Language Transfer in Language Learning. Amsterdam: John Benjamins.

Grosz, B., \& Sidner, C. L. (1986). Attention, intention, and the structure of discourse. Computational Linguistics, 12(3), 175-204.

Gundel, J., Hedberg, N., \& Zacharski, R. (1988). On the generation and interpretation of demonstrative expressions. International Conference on Computational Linguistics, Proceedings of the 12th Conference on Computational Linguistics, 1, 216-221.

Gundel, J. K., Hedberg, N., \& Zacharski, R. (2004). Demonstrative Pronouns in natural discourse. Paper presented at the Fifth Discourse Anaphora and Anaphora Resolution Colloquium, Sao Miguel, Portugal, Sept. 23-24, 2004. Retrieved from http://www.sfu.ca/ hedberg/GHZ_DAARC2004Final.pdf

Hyland, K. (2003). Second Language Writing. Cambridge: Cambridge University Press.

Levelt, W. J. M. (1989). Speaking: From Intention to Articulation. Cambridge, MA: MIT Press.

Lyons, J. (1977). Semantics Vol.2. Cambridge: Cambridge University Press.

Mann, W. C., \& Thompson, S. A. (1988). Rhetorical Structure Theory: Toward a functional theory of text organization. Text, 8, 244-277.

Marcu, D. (2000). The Theory and Practice of Discourse Parsing and Summarization. Cambridge, MA: MIT Press.

Matsuda, P. K., Canagarajah, A. S., Harklau, L., Hyland, K., \& Warschauer, M. (2003). Changing currents in second language writing research: A colloquium. Journal of Second Language Writing, 12, 151-179.

Moeschler, J. (2004). Intercultural pragmatics: a cognitive approach. Intercultural $\begin{array}{llll}\text { Pragmatics, } & 1, & \text { 49-70. } & \text { Retrieved }\end{array}$ https://www.degruyter.com/journals/intcultpragm /pdf/moeschler.pdf

Murphy, T. (2001). The emergence of texture: an analysis of the functions of the nominal demonstratives in an English interlanguage corpus. Language Learning \& Technology, 5 (3), 152-173.

Niimura, T., \& Hayashi, B. (1996). Contrastive analysis of English and Japanese demonstratives from the perspective of L1 and L2 acquisition. Language Sciences, 18 (3-4), 811-834.

Papadopoulou, D., \& Clahsen, H. (2003). Parsing strategies in L1 and L2 sentence processing: A study of relative clause attachment in Greek. Studies in Second Language Acquisition, 24, 501-528.

Roberts, L., Gullberg, M., \& Indefrey, P. (2008). Online pronoun resolution in L2 discourse: L1 influence and general learner effects. Studies in Second Language Acquisition, 30(3), 333-357.

Ruhi, Ş. (1990). Kalem sürçmeleri ve düzeltmeler [Slips of the pen and editing]. In $I V$. Dilbilim Sempozyumu Bildirileri, 17-18 Mayıs 1990, A. S. Özsoy and H. Sebüktekin (eds.), 103-120. İstanbul: Boğaziçi Üniversitesi Yayınları. 
Skehan, P. (1996). A framework for the implementation of task-based instruction. Applied Linguistics, 17(1), 38-62.

Sperber, D. \& Wilson, D. (1986). Relevance: Communication and Cognition. (2 ${ }^{\text {nd }}$ ed.). Oxford: Blackwell.

Strauss, S. (2002). This, that and it in spoken American English: a demonstrative system of gradient focus. Language Science, 24, 131-152.

Streb, J., Rösler, F., \& Hennighausen, E. (1999). Event-related responses to pronoun and proper name anaphors in parallel and nonparallel discourse structures. Brain and Language, 70, 273-286.

Taboada, M., \& Mann, W. (2005). Applications of rhetorical structure theory. Discourse Studies, 8(4), 567-588.

Webber, B. L. (1988). Discourse deixis: reference to discourse segments. Proceedings of the 26th Annual Meeting on Association for Computational Linguistics. Buffalo, New York: $113-122$.

Webber, B. L. (1991). Structure and ostension in the interpretation of discourse deixis. Language and Cognitive Processes, 6(2), 107-135.

Wilson, D., \& Sperber, D. (1993). Linguistic form and relevance. Retrieved from http://sperber.club.fr/form.htm

Wilson, D., \& Sperber, D. (2002). Relevance theory. UCL Working Papers in Linguistics, $14,249-287$.

Wilson, F. (2009). Processing at the syntax-discourse interface in second language acquisition. (Unpublished doctoral dissertation). University of Edinburgh, Edinburgh, UK. 


\section{Appendix}

INSTRUCTION: Please read the following texts carefully and choose the word that

$\underline{\text { best }}$ completes the sentence.

\section{Many thanks for your cooperation!}

I am not saying that there are no native speakers of English any more- if by native speakers we mean persons who were born and brought up in monolingual homes with no contact with other languages. Indeed, (1) would be an absurd thing to say.
(1) a. it
b. that
c. this

In research on writing, although there have been studies on what native speakers do when they plan, few studies have focused on the effects of planning on second language writing. (2)....... is surprising when the importance attached to the planning stage in teaching is taken into consideration.
(2) a. this
b. it
c. that

Non-Western teachers may have different ideas about their roles and duties in the classroom. For example, Mai, a teacher of English in Vietnam, encourages her students to have free, lively discussions so that they can learn English better. In this manner, she is a good English teacher. But as a good Vietnamese teacher, she also performs her role as a guide to 'good behavior'. Mai says "When my students behave badly, I am willing to tell them that they are wrong and that they should do this or that." In doing (3)......., Mai did not 'lead' her students or force her ideas on them, but she still fulfilled the responsibility of a teacher who is socially expected to educate students. More than (4)......., Mai was a 'guide' in teaching in several ways. (5) .......can make the West think of the East as having no Western qualities.
(3) a. it
b. this
c. that
(4) a. that
b. it
c. this
(5) a. this
b. it
c. that 
Smith demonstrated in his article that homelessness is not caused by capitalism, but Kozol explains that (6) ........is not right.
(6) a. that
b. this
c. it

Segal had his own problems with women; he had been trying to keep his marriage from falling apart. When (7)........became impossible he accepted to divorce.
(7) a. this
b. it
c. that

Although it is difficult to come up with any strong conclusion based on the small number of texts analyzed, the results indicate that most recent textbooks have begun to include more of the language characteristics found in real life dialogues. The examples of repetitions and hesitation markers have increased. Having said

(8) ........, the number of repetitions and hesitations markers is still below those in real life dialogues.
(8) a. this
b. it
c. that

In research on vocabulary, the problem for researchers is that it is impossible to get inside people's heads and observe how their vocabularies are organized, and how this organization interacts with vocabulary loss. (9) ........means that in real life we do not have real research methodologies other than (10)........reported in studies on vocabulary loss. However, (11) .........does not mean that it is impossible for us to explore the way vocabulary loss might work.
(9) a. this
b. it
c. that
(10) a. that
b. it
c. this 
(11) a. it

b. this

c. that

The higher number of vocabulary items found in course book texts is more similar to written texts than spoken texts, and (12) ........is not surprising since (13) ........is essentially what it is.

(12) a. it $\quad$ b. this

c. that

(13) a. that

b. this

c. it 